doc. dr. sc. Dejan Jovanović

Ekonomski fakultet, Univerzitet u Kragujevcu, Kragujevac, Srbija

djovanovic@kg.ac.rs

dr. sc. Ivana Medved

Ekonomski fakultet, Univerzitet u Novom Sadu, Subotica, Srbija

ivana@ef.uns.ac.rs

\title{
RAZVOJ I NUŽNOST PROMJENE FOKUSA UPRAVLJAČKOG RAČUNOVODSTVA
}

Primljen: 28. kolovoza 2018.

Prihvaćen: 5. listopada 2018.

Pregledni rad

\section{Sažetak}

U posljednje dvije decenije ambijent u kome upravljačko računovodstvo ostvaruje svoju ulogu počinje da se ubrzano mijenja. Sukladno promjenama koje su se odigrale u okruženju, poduzećima i menadžmentu, računovođe su morale redizajnirati postojeći računovodstveni informacijski sustav. S obzirom na to da upravljačko računovodstvo predstavlja najdinamičniji dio tog sustava, sukladno očekivanjima ono je pretrpjelo najveći dio promjena. Upravo cilj istraživanja u ovom radu je da ukaže na evolutivni put upravljačkog računovodstva, njegovu trenutnu poziciju i buduće pravce razvoja. Polazeći od navedenog u radu će biti primijenjeni metodološki postupci i tehnike svojstvene društvenim znanostima, tj. kvalitativna metodologija bazirana na proučavanju i deskriptivnoj analizi definiranog cilja istraživanja. Najvažniji zaključak je da upravljačko računovodstvo svoj fokus sve više pomjera prema strategijskoj dimenziji poslovanja i konceptu održivog razvoja, kao i da postoji neravnoteža između teorije i prakse upravljačkog računovodstva.

Ključne riječi: upravljačko računovodstvo, strategijsko upravljačko računovodstvo, ekološko upravljačko računovodstvo, obračun troškova na bazi aktivnosti

JEL: M41 


\section{UVOD}

Veliki broj istraživanja, kao i praksa nedvosmisleno ukazuje na vezu između efikasnog upravljanja i upravljačkog računovodstva. Ta veza je toliko čvrsta da bi se moglo reći da upravljačko računovodstvo bez potreba menadžera za informacijama ne bi imalo smisla, baš kao što ni menadžeri bez upravljačkog računovodstva nemaju mnogo šansi za uspjeh u konkurentskom okruženju. Činjenica je da su upravljački problemi svuda prisutni i da njihovo rješavanje zahtijeva, između ostalog, kvalitetniju informatičku podršku (Malinić i dr., 2012a, i). Tragajući za informacijama menadžeri su godinama upućeni na upravljački i računovodstveni informacijski sustav koji jedan pored drugog postoje u većini kompanija razvijenog poslovnog svijeta. Prema tome, može se reći da upravljačko računovodstvo predstavlja svojevrsnu vezu između upravljačkog i računovodstvenog informacijskog sustava, pri čemu je osnovni zadatak upravljačkog informacijskog sustava da opskrbljuje menadžere (top, middle and lower management) relevantnim informacijama koje će biti podloga za donošenje brojnih strateških, operativnih i taktičkih odluka (Milićević, 2003, 73). Sama pojava upravljačkog računovodstva koincidirala je sa pojavom brojnih menadžerskih potreba za različitim informacijama, na koje financijsko računovodstvo, zbog svoje tradicionalne usmjerenosti na povijesne aspekte eksternog polaganja računa, nije moglo dati adekvatne odgovore. Vremenom su informacijske potrebe menadžera postojale sve obimnije i brojnije što je dovelo do dinamičnog razvoja i velike fleksibilnosti upravljačkog računovodstva. Međutim, u posljednje dvije decenije ambijent u kome upravljačko računovodstvo ostvaruje svoju ulogu počinje da se ubrzano mijenja. Sukladno promjenama koje su se odigrale u okruženju, poduzećima i menadžmentu, računovođe moraju redizajnirati postojeći računovodstveni informacijski sustav. S obzirom na to da upravljačko računovodstvo predstavlja najdinamičniji dio tog sustava, realno je očekivati da će ono pretrpjeti najveći dio promjena. Imajući navedeno u vidu cilj istraživanja u ovom radu je da ukaže na evolutivni put upravljačkog računovodstva, njegovu trenutnu poziciju i buduće pravce razvoja. Polazeći od cilja istraživanja u radu će biti primijenjeni metodološki postupci i tehnike svojstveni društvenim znanostima, tj. kvalitativna metodologija bazirana na proučavanju i deskriptivnoj analizi teorijskih i empirijskih radova prije svega sa engleskog govornog područja.

Rad je strukturiran u šest dijelova. Nakon uvoda, u drugom i trećem dijelu se ukazuje na razvoj i ograničenja konvencionalnog upravljačkog računovodstva. U četvrtom dijelu ukazano je na promjenu fokusa upravljačkog računovodstva ka strateškoj dimenziji poslovanja i konceptu održivog razvoja. Nakon toga, u petom djelu ukazano je na neravnotežu između teorije i prakse upravljačkog računovodstva. Konačno, u šestom dijelu dani su zaključci, doprinos rada i smjernice za dalja istraživanja. 


\section{EVOLUCIJSKI PUT UPRAVLJAČKOG RAČUNOVODSTVA}

Razvoj upravljačkog računovodstva su uvjetovali ključni eksterni faktori kao što su: globalizacija poslovanja i tehnološki napredak, kao i promjene unutar samih organizacija izazvane, između ostalog, i djelovanjem naprijed navedenih faktora. Intenzitet $i$ učestalost djelovanja ovih faktora vrše snažan pritisak na menadžment poduzeća, a samim tim i na upravljačke računovođe koji danas uživaju prepoznatljiv imidž u poslovnom svijetu i sve češće se pojavljuju kao suradnici koji svojim stručnim savjetima i informacijama kojima raspolažu pomažu u traženju pouzdanog oslonca za razvoj i implementaciju ideja na različitim hijerarhijskim nivoima (Malinić et al., 2012b, 298-300). Uvažavajući navedeno, kao glavni razlozi koji su doprinijeli evoluciji upravljačkog računovodstva, po mišljenju autora, mogu se izdvojiti:

1. povećanje općih troškova u ukupnim troškovima - najznačajnija promjena troškova poslovanja ogleda se u porastu općih troškova i smanjenju direktnih troškova u odnosu na ukupne troškove,

2. promjena oblika organizacija i načina poslovanja - uz proizvodne organizacije, na tržištu sve značajnije postaju trgovinske i uslužne organizacije, ali nastaju i velike organizacije (korporacije i sl.), koje su divizijske i sadrže različite segmente poslovanja,

3. međunarodno tržište - pojava međunarodnih korporacija doprinosi povećanju složenosti obračuna troškova, raste značaj formiranja transfernih cijena i dr.,

4. traženje novih načina da se postigne održiva (trajna) konkurentnost - obračun troškova treba da pruži informacije o proizvodima, ali i o tržištima, kupcima i konkurenciji,

5. nastanak i razvoj strategijskog upravljanja troškovima - poslovanje je nezamislivo bez upravljanja troškovima,

6. jačanje uloge i značaja nefinancijskih mjerila performansi,

7. nastanak i razvoj ekološkog upravljačkog računovodstva - u funkciji podrške postizanju održivih, konkurentskih prednosti i održivog razvoja.

Imajući u vidu da se uloga upravljačkog računovodstva promijenila i da se sadašnjost može potpuno razumjeti tek u svjetlu prošlosti, čini se značajnim ukazati na evolutivni put upravljačkog računovodstva.

Faze u razvoju upravljačkog računovodstva nije jednostavno definirati, a još teže je povući neke precizne granice između njih. Međunarodna federacija računovođa (The International Federation of Accountants - IFAC) identificirala je četiri faze $^{1} \mathrm{u}$ evoluciji upravljačkog računovodstva (slika II/1).

U literaturi se također, pored evolucije upravljačkog računovodstva predstavljene od strane Međunarodne federacije računovođa, navodi i evolucija upravljačkog računovodstva dana od 
Slika 1. Evolucija upravljačkog računovodstva

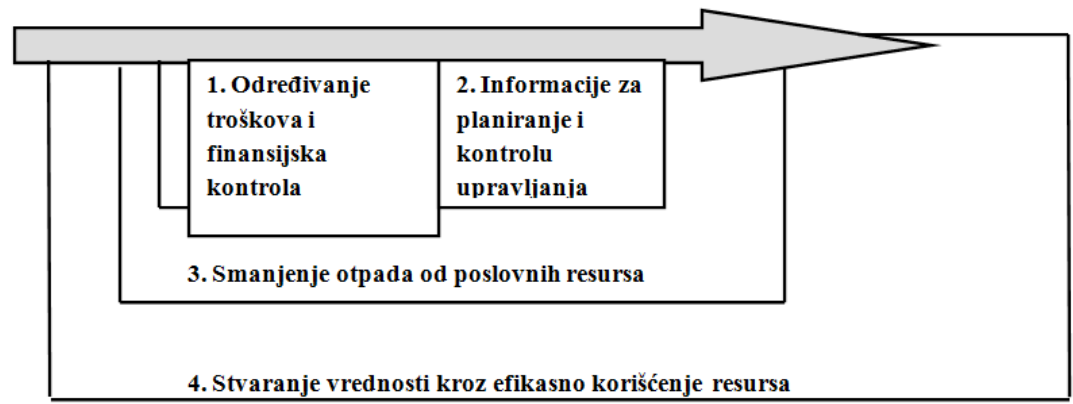

Izvor: International Federation of Accountants Committee (IFAC). (1998). Management accounting concepts, March. str. 6.

Prva faza obuhvaća razdoblje od nastanka upravljačkog računovodstva do 1950 . godine i akcent stavlja na određivanje troškova i financijsku kontrolu. S obzirom na to da je akcent u ovoj fazi na određivanju troškova, vodeći autori iz oblasti računovodstva smatraju da je razvoj koncepta upravljačkog računovodstva otpočeo sa pojavom računovodstva troškova, koje je usmjereno na pune troškove i kalkulaciju cijene koštanja za vrednovanje zaliha u svrhe bilanciranja rezultata. Od velikog značaja za razvoj upravljačkog računovodstva je pojava velikih korporativnih multidivizijskih poduzeća početkom XX stoljeća, kao što su Du Pont i General Motors, koja su u cilju efikasnog upravljanja svojim poslovanjem razvili sustav financijske kontrole. Ovu fazu karakterizira usporen razvoj upravljačkog računovodstva.

Druga faza obuhvaća razdoblje do 1965. godine i akcent stavlja na osiguranje informacija za potrebe planiranja i kontrole upravljanja. U okviru ove faze dolazi do pune afirmacije teze Džona Klarka (John Clark), različiti troškovi za različite svrhe i i do izražaja dolazi primjena obračuna po varijabilnim troškovima. Primjena ovog obračuna troškova je omogućila drugačiji način razmišljanja računovođa i dovela do operacionalizacije marginalnih, diferencijalnih i oportunitetnih troškova. Također, za ovu fazu se vezuje i nastanak računovodstva odgovornosti.

strane Kaplana (Kaplan, 1982). Kaplan navodi da je upravljačko računovodstvo u svom razvoju prošlo kroz tri faze i to: faza apsolutno istinitih informacija; faza uslovno istinitih informacija i faza ekonomično istinitih informacija. Ovim fazama je kasnije dodana i faza informiranja koja uvažava efekte na ponašanje pojedinaca i grupa - bihejvioristička faza (detaljnije pogledati: Kaplan, 1982; Milićević, 2003). Također, u cilju što boljeg sagledavanja suvremenih tendencija razvoja u upravljačkom računovodstvu, značajno je pored evolucije upravljačkog računovodstva $\mathrm{u}$ anglosaksonskoj literaturi, navesti i faze razvoja u istočnoj (kinesko-japanskoj) literaturi, s obzirom na utjecaj japanske ekonomije na razvoj svjetske privrede i suvremenih koncepata i tehnika u menadžmentu i računovodstvu. Profesor Akira Nishimura (2002) opisuje razvoj upravljačkog računovodstva u Japanu kroz četri faze: plutajuće (Drifting), tradicionalno, kvantitativno i integrirano upravljačko računovodstvo (detaljnije pogledati Nishimura, 2002). 
Treća faza obuhvaća razdoblje do 1985. godine i karakterizira je efikasno korištenje resursa u poslovnim procesima, odnosno usmjerena je na smanjenje otpada od korištenja resursa. Ova faza akcent stavlja na internu efikasnost i obuhvaća analizu procesa i primjenu nekih tehnika upravljanja troškovima. Također, kao glavno obilježje ove faze se ističe bihejvioristička dimenzija, ${ }^{2}$ imajući u vidu da Robert Kplan ovo vremensko razdoblje označava kao fazu informiranja uz uvažavanje efekata na ponašanje pojedinaca i grupa (Kaplan, 1982, 2-4).

Četvrta faza $a^{3}$ obuhvaća razdoblje do 1995 . godine i fokus je na generiranju vrijednosti kroz djelotvorno (efektivno) i efikasno korištenje resursa. Usmjeravanje pažnje na događanja u eksternom okruženju (kupce, dobavljače, konkurenciju, kreditore i sl.) utjecalo je na unaprjeđenje ponude informacija upravljačkog računovodstva koja se pomjera k centralnom menadžmentu. U ovoj fazi je naglašena strateška dimenzija, pa se ova faza često poistovjećuje sa razvojem strateškog upravljačkog računovodstva.

Imajući u vidu poziciju upravljačkog računovodstva u drugoj deceniji XXI stoljeća može se reći da je, pored daljeg razvoja suvremenih upravljačko računovodstvenih tehnika, jedno od glavnih obilježja pete faze razvoj i usavršavanje upravljačkog računovodstva usmjerenog ka održivom razvoju, a posebno ekološkog upravljačkog računovodstva (Environmental Management Acounting - EMA). Navedeni stav je potkrepljen činjenicom da je američka Agencija za zaštitu životne sredine krajem XX. stoljeća uspostavila formalni program za promoviranje usvajanja EMA. Ovom programu su se u narednom razdoblju pridružile organizacije u više od trideset zemalja sveta (UNDESA/DSD, 2002). Promoviranju EMA se pridružio i IFAC 2004. godine objavljivanjem smjernica za EMA. Akcent $u$ ovoj fazi je stavljen na sagledavanje utjecaja poduzeća na životnu sredinu i njihovo izražavanje u financijskim i nefinancijskim terminima. Međutim, potrebno je istaći da EMA predstavlja sastavni dio upravljačkog računovodstva, a ne paralelni sustav.

Svaka od navedenih faza predstavlja kombinaciju stare i nove, pri čemu se za treću, četvrtu i petu fazu može reći da predstavljaju sastavni dio procesa upravljanja. Razvojem suvremenih tehnologija, informacije postaju dostupne blagovremeno i na svim razinama upravljanja. Dakle, sa razvojem upravljačkog računovodstva fokus se pomjera ka generiranju vrijednosti za sve interesne skupine poduzeća (Waweru, 2010, 167). Prema IFAC analizi, upravljačko-računovodstvena praksa se pomjera dalje od pružanja informacija, ka efikasnom korištenju resursa,

2 Detaljnije o bihejviorističkoj fazi razvoja upravljačkog računovodstva pogledati: Milićević, 2003, 87-93.

3 Međunarodna federacija računovođa je evolutivni put upravljačkog računovodstva objavila 1998. godine, stoga je i razumljivo što se četvrta faza završava 1995. godine i što predstavlja posljednju fazu. 
generiranju vrijednosti, sagledavanju i mjerenju utjecaja poduzeća na životnu sredinu, odnosno uloga upravljačkog računovodstva u poduzeću je u skladu s tim evoluirala od praćenja informacija k strateškoj ulozi u formuliranju i implementaciji strategija, kao i u planiranju, kontroli i izvještavanju o utjecajima poduzeća na životnu sredinu.

Navedene faze ukazuju da je konvencionalno upravljačko računovodstvo usmjereno kako na monetarne, tako i na nemonetarne informacije (npr. uzročnici troškova mogu biti radni sati, količine nabavljenih sirovina i sl.) stvarajući na taj način informacijsku bazu koja omogućava: efikasnije odlučivanje i planiranje, efikasnije korištenje resursa, mjerenje performansi, formuliranje poslovne politike i strategije, čiji je zajednički cilj kreirati, zaštiti i povećati vrijednost za interesne skupine poduzeća. Međutim, iako se na bazi navedenih faza može reći da se upravljačko računovodstvo ubrzano razvija i da svaka naredna faza predstavlja nadogradnju prethodne, rezultati empirijskih istraživanja u svijetu ukazuju da se upravljačkom računovodstvu upućuju i brojne kritike (Milićević, 2003). Naime, u posljednje tri decenije, pod utjecajem istraživanja Džonsona (Johnson), Kaplana (Kaplan) i Kupera (Cooper) napisan je veliki broj radova u kojima su razmatranja tekućih kontraverzi upravljačkog računovodstva potpomognuta povijesnim studijama. Brojni autori sa pravom ističu da je to najbolji način da se pronađu pravi putevi za razvoj upravljačkog računovodstva u budućnosti (Johnson \& Kaplan, 1987; Bromwich \& Bhimani, 1996; Nishimura, 2002; Milićević, 2003; Kamal, 2015).

\section{OGRANIČENJA KONVENCIONALNOG UPRAVLJAČKOG RAČUNOVODSTVA}

Među najoštrijim kritičarima konvencionalnog upravljačkog računovodstva, devedesetih godina XX. stoljeća, ističe se profesor Robert Kaplan. Oslanjajući se na istraživanja vodećih autora iz oblasti upravljačkog računovodstva, Milićević (2003, 95-111) kritike upućene konvencionalnom upravljačkom računovodstvu sistematizira u sljedeće četiri grupe:

1. Konvencionalno upravljačko računovodstvo ne odgovara potrebama suvremenog proizvodnog i konkurentskog okruženja. Uvođenje računalnih integriranih sustava proizvodnje i just-in-time (JIT) proizvodnih tehnika radikalno su izmijenile proizvodne procese u mnogim poduzećima. Kao posljedica toga konkurencija između proizvođača je poprimila neslućene razmjere. Međutim, investiranje u napredne proizvodne tehnologije prouzrokovalo je brojne probleme, kao što su: kako procjenjivati kapitalne investicije, kako obračunavati troškove proizvoda, kako modificirati sistem kontrole i sistem mjerenja performansi kako bi menadžeri bili motivirani da ostvaruju postavljene 
strateške i konkurentske ciljeve poduzeća i sl. (Milićević, 2003, 95-100). Stoga, predmet interesa suvremenog upravljačkog računovodstva treba da bude usmjeren $\mathrm{k}$ rješavanju navedenih problema.

2. Tradicionalni sistemi obračuna troškova osiguravaju pogrešne informacije za potrebe poslovnog odlučivanja. Cooper i Kaplan (1988) među prvima skreću pažnju na određena ograničenja tradicionalnih sustava obračuna troškova koja se odražavaju na područjima mjerenja troškova i analize profitabilnosti. Tradicionalni sustavi obračuna troškova nastali su u uvjetima kada na tržištu nije bilo velikih oscilacija i neizvjesnosti, kada proizvodni asortimani poduzeća nisu bili diverzificirani, kada je bila zastupljena masovna proizvodnja, a u strukturi troškova većinski dio je pripadao troškovima direktnog rada i materijala, dok su opći troškovi imali veoma mali udio u ukupnim troškovima (Jovanović i dr., 2014, 1097). Međutim, poslovni svijet krajem XX. stoljeća bio je daleko od ove jednostavnosti, tako da tradicionalni sustav obračuna troškova nisu bili u stanju da osiguraju korisne informacije za potrebe poslovnog odlučivanja. U novonastalim okolnostima opći troškovi su obilježili veliki porast u odnosu na direktne troškove, tako da alokacija općih troškova na bazi troškova direktnog rada u novonastalim okolnostima daje lažnu sliku o profitabilnosti pojedinih proizvoda, grupa proizvoda i organizacijskih dijelova poduzeća. Cooper i Kaplan kao protutežu tradicionalnim sustavima obračuna troškova i kao moguće rešenje navedenog problema vide u obračunu troškova na bazi aktivnosti (Activity Based Costing - ABC).

3. Konvencionalna praksa upravljačkog računovodstva u početnim fazama razvoja upravljačkog računovodstva u velikoj mjeri je bila podređena zahtjevima financijskog računovodstva. Kao i ostale kritike upućene konvencionalnom upravljačkom računovodstvu i ova se zasniva na rezultatima empirijskih istraživanja koja ukazuju da se u većini američkih poduzeća obračunati troškovi proizvoda za potrebe financijskog izvještavanja istovremeno koriste i za potrebe poslovnog odlučivanja. Obračunati troškovi proizvoda prema načelima financijskog računovodstva osiguravaju prihvatljivu aproksimaciju za razgraničavanje troškova prodanih proizvoda od troškova nerealiziranih učinaka, ali oni istovremeno iskrivljuju informacije o individualnim troškovima proizvoda zbog čega su čak i strateške odluke podređene zahtjevima financijskog računovodstva. Drury (1993) svoje izlaganje o ovom problemu potkrepljuje istraživanjem koje pokazuje da mnoge kompanije u Ujedinjenom Kraljevstvu nisu razvile sofisticirane sustave obračuna troškova zato što su sumnjale u opravdanost ulaganja u takve sustave (Milićević, 2003, 106-107).

4. Upravljačko računovodstvo je uglavnom posvećeno internim aktivnostima i relativno malo pažnje posvećuje eksternom okruženju u kome posluje poduzeće. Sve veći broj autora, u stručnoj literaturi sa kraja XX. stoljeća, 
konvencionalnom upravljačkom računovodstvu zamjera što je uglavnom posvećeno internom uparivanju troškova i koristi i što relativno malo pažnje posvećuje eksternom okruženju. Zato se sve više autora zalaže za razvoj, pored interne, strategijske dimenzije upravljačkog računovodstva koja podrazumijeva širenje njegovih vidika na informacije koje se odnose na eksterne interesne skupine. Ovakvi zahtjevi za informacijama, koji su posljedica promjenljivih uvjeta poslovanja, šire fokus interesa upravljačkih računovođa ka tržištima i konkurentnim poduzećima. Otuda značajno izvorište, jedan potpuno nov koncept i širi opseg informacija, postaje strategijsko upravljačko računovodstvo. Stoga, strateško upravljačko računovodstvo ima zadatak da menadžmentu poduzeća osigura širu bazu informacija koja će sadržati glavne elemente strateškog upravljanja (Brouthers \& Roozen, 1999, 312-317).

Uvažavajući navedene kritike, kao ograničenje se može navesti i da konvencionalno upravljačko računovodstvo ne sagledava utjecaje poduzeća na životnu sredinu, odnosno ne daje adekvatan doprinos procesu upravljanja zaštitom životne sredine, identificiranju, mjerenju i alokaciji ekoloških troškova, donošenju poslovnih odluka sa ekološkim utjecajima, mjerenju, upravljanju i izvještavanju o ekološkim performansama. Burritt (2004) ukazuje na niz ključnih „ekoloških“ kritika upućenih konvencionalnom upravljačkom računovodstvu. Ne razmatrajući u ovom radu načine za rješavanje kritika u teoriji i praksi na koje ukazuje Burritt u svom radu „Environmental Management Accounting: Roadblocks on the way to the green and pleasant land“", u nastavku su navedene ključne kritike upućene konvencionalnom upravljačkom računovodstvu, i to (Burritt, 2004, 15):

1. polazi se od pretpostavke da troškovi zaštite životne sredine nisu važni,

2. indirektni troškovi zaštite životne sredine se najčešće svode na opće režijske troškove poslovanja,

3. tehnike vrednovanja performansi su previše uske i njihov fokus je kratkoročan,

4. procjena investicija isključuje pitanja životne sredine,

5. uski fokus na proizvodnju,

6. dominantna financijsko računovodstvena pravila,

7. odsustvo računovodstva za eksternalije.

Na osnovu navedenog može se zaključiti da je fundamentalna ,ekološka“ kritika upućena konvencionalnom upravljačkom računovodstvu da ono u velikoj mjeri ignorira zasebno identificiranje, klasificiranje, mjerenje i izvještavanje o utjecajima poduzeća na životnu sredinu i životne sredine na poduzeća, posebno o troškovima zaštite životne sredine, prilikom pružanja relevantnih informacija za upravljanje u procesu donošenja odluka, planiranju i kontroli (Burritt \& Saka, 2006, 1263). 
Međutim, treba istaći da upućene kritike konvencionalnom upravljačkom računovodstvu nikako ne umanjuju njegov značaj koji se ogleda u tome da ono generira informacije koje su relevantne za proces odlučivanja menadžmenta (obračun troškova i učinaka, računovodstveno planiranje i računovodstvena kontrola). Ograničenja i kritike upućene konvencionalnom upravljačkom računovodstvu, potaknute dinamičnim privrednim razvojem, turbulentnošću tržišta, nepredvidivom konkurencijom i promjenama unutar samog poduzeća, su navedeni s ciljem da se ukaže da su izmijenjeni uvjeti poslovanja u proteklim decenijama doveli do širenja i promjene fokusa interesa upravljačkog računovodstva ka strateškoj dimenziji poslovanja i konceptu održivog razvoja.

\section{USMERENOST UPRAVLJAČKOG RAČUNOVODSTVA PREMA STRATEGIJSKOJ DIMENZIJI POSLOVANJA I KONCEPTU ODRŽIVOG RAZVOJA}

Sve do početka devedesetih godina XX. stoljeća upravljačke računovođe su se uglavnom u većini poduzeća bavile obračunom troškova i informacijskom podrškom kontrolnim aktivnostima menadžmenta. Najveća pažnja računovođa u to vrijeme bila je posvećena razumijevanju tzv. internih troškova poduzeća. U skladu s tim konvencionalno upravljačko računovodstvo se mnogo više interesiralo za proizvodne nego za sve druge aktivnosti unutar poduzeća. Kao posljedica svega toga mali broj upravljačkih računovođa je do početka devedesetih godina pokazivao interes za informacije koje potiču izvan poduzeća, kao i na sagledavanje utjecaja poduzeća na životnu sredinu i okruženje. Također, sprovedena istraživanja pokazuju da je upotreba eksternih informacija prilikom formuliranja strategija poduzeća bila prije izuzetak nego pravilo (Milićević, 2003, 115). Međutim, uvažavanje događaja u okruženju nije stvar izbora, već pitanje od strategijskog značaja za uspješno funkcioniranje poduzeća.

Iako su brojni autori iz oblasti upravljačkog računovodstva (prije svega Cooper i Kaplan, 1988; Nishimura, 2002; Milićević, 2003; Burritt, 2004) prepoznali neka od ograničenja konvencionalnog upravljačkog računovodstva, oni i dalje usmjeravaju pažnju k internim troškovima poduzeća. Međutim, za razliku od ranijih praksi, autori se zalažu za mjerenje troškova proizvoda na način koji će bolje oslikati aktivnosti koje su inicirane njihovom proizvodnjom i prodajom. Tako je i nastao novi koncept obračuna troškova - obračun troškova na bazi aktivnosti (Activity Based Costing - ABC) čija je primjena dovela do značajnih redukcija aktivnosti koje ne dodaju vrijednost. $\mathrm{ABC}$ proglašava aktivnosti, koje se provode u okviru poduzeća, za glavne izazivače troškova, iako su iz strateške perspektive koristi koje proizvodi osiguravaju krajnjim kupcima jedini pravi izazivači troškova. Navedeni nedostatak strateške relevantnosti predstavlja jedan od glavnih problema sa kojima se suočava konvencionalno upravljačko računovodstvo. 
Ovdje također, treba istaći da su poduzeća u Japanu primjenjivala jedan potpuno drugačiji koncept. Naime, osnovna uloga upravljačkih računovođa u Japanu bila je da svojim informacijama pomognu dostizanje tzv. ciljnih cijena (target prices) i da pomognu u stvaranju onih karakteristika proizvoda koje kupcima osiguravaju veću dodatnu vrijednost nego proizvodi konkurencije. U vezi s tim, u čitavom Japanu forsira se jedinstvena upravljačka filozofija po kojoj je rast i razvoj poduzeća neraskidivo povezan sa kontinuiranim poboljšanjem karakteristika proizvoda i smanjenjem troškova njihovog osiguranja. Iz ovog proizlazi da se od upravljačkog računovodstva ne očekuje da bude samo sredstvo puke kontrole i procjene, već i da ohrabruje menadžere da kontinuirano tragaju za smanjenjem troškova i poboljšanjem dugoročne proizvodne strategije.

Kako početkom devedesetih godina XX. stoljeća japanska poduzeća sve više šire poslovanje na tržišta Zapada, to zahtjeva radikalnu promjenu poslovne prakse poduzeća na Zapadu, kao i preuzimanje i unaprjeđenje određenih iskustava japanskih kompanija i njihovog menadžmenta. Poduzeća na Zapadu su bila primorana da se zarad svog opstanka i rasta moraju globalno natjecati na mnogo širem dijapazonu strateških varijabli nego što su prodajne cijene (Milićević, 2003, 117). U prilog tome svjedoče i izvještaji koji su nastali upravo tih godina od strane Bromwich $\mathrm{i}$ Bhimani (1996), koji skreću pažnju ka strateškom upravljačkom računovodstvu kao oblasti koja će predstavljati perspektivu budućeg razvoja. Bromwich (1990, 28-32) koji se smatra jednim od glavnih pobornika strategijskog upravljačkog računovodstva ističe da ga treba promatrati u kontekstu:

1. opskrbe, praćenja i analize financijskih informacija na proizvodnom tržištu poduzeća,

2. praćenja i analize troškova konkurencije i troškova strukture proizvoda,

3. projekcije i analize strategija poduzeća, konkurencije na danim tržištima tokom životnog vijeka poduzeća.

Prema tome, fokus konvencionalnog upravljačkog računovodstva se pomjera ka strateškom upravljačkom računovodstvu, ali i sagledavanju utjecaja poduzeća na životnu sredinu i na socijalnu dimenziju poslovanja. Dakle, fokus upravljačkog računovodstva u suvremenim uvjetima poslovanja trebalo bi karakterizirati dinamički pristup, timski rad, širok, interni i eksterni proaktivni pogled na događanja u budućnosti, jer od mogućnosti poduzeća da predvidi i reagira na izazove iz okruženja ovisi njegova konkurentska sposobnost. Informacijski portfelj strateškog upravljačkog računovodstva čine: integrirane financijske i nefinancijske, odnosno računovodstvene i neračunovodstvene, interne i eksterne, kvalitativne i kvantitativne informacije (Janjić i Jovanović, 2016, 375).

Literatura iz oblasti strateškog upravljačkog računovodstva ukazuje na dvije perspektive u razvoju. Prva, strateško upravljačko računovodstvo obuhvaća niz 
strategijski orijentiranih računovodstvenih tehnika. Strateški orijentirane računovodstvene tehnike se razlikuju od konvencionalnih po svojoj eksternoj (orijentirane na sagledavanje stanja u okruženju) i dugoročnoj orijentaciji, procjeni budućih zbivanja i obuhvatu svih elemenata u lancu vrijednosti. Druga, nova uloga upravljačkih računovođa odražava se u njihovom aktivnom sudjelovanju u formuliranju i implementaciji strategija i strateškom procesu donošenja odluka. U turbulentnim uvjetima poslovanja, poduzeća su najčešće horizontalno organizacijski strukturirana te se odluke donose od strane višefunkcionalnog menadžerskog tima u koji je uključen i upravljački računovođa. Otuda, upravljački računovođa ima zadatak transformirati računovodstvene podatke i pokazatelje u upravljačko računovodstveni izvještajni sustav sa svrsishodnim informacijskim sadržajem (Cadez \& Guilding, 2008, 839-840).

Analizirajući razvoj i fokus upravljačkog računovodstva, može se zapaziti ozbiljan napredak i promjene karakteristika koje definiraju upravljačko računovodstvo u odnosu na prvobitno definirane specifičnosti. Naime, uvjeti poslovanja su nametnuli promjenu mjesta i uloge koju je ranije upravljačko računovodstvo zauzimalo, tako da sadržaj suvremenog upravljačkog računovodstva danas, pored interne, određuju njegova eksterna orijentacija i dinamičan pristup, sagledavanje socijalne dimenzije poslovanja, utjecaja poduzeća na životnu sredinu kao i težnja ka uspostavljanju veza među organizacijskim strategijama kako bi se realizirale dionice poduzeća.

Pojava strateškog upravljačkog računovodstva je značajno osnažila informacijsku podršku strateškom menadžmentu. Naime, strateškom menadžmentu se umjesto sporadičnih neformalnih savjeta i uglavnom sirovih podataka, najčešće osiguranih od strane vanjskih konsultanata, omogućavaju relevantne informacije koje mogu da postanu vrijedno konkurentsko oruđe zahvaljujući širenju informacijske ponude upravljačkog računovodstva. Na taj način upravljačke računovođe mogu da postanu važni članovi top menadžmenta koji aktivno sudjeluju u izboru strateških opcija. Također, u upravljačko računovodstvenoj literaturi sa kraja XX. i početka XXI. stoljeća sve više se ukazuje na ograničenja konvencionalnog računovodstva koja se odnose na osiguranje informacija povezanih sa održivim razvojem (socijalnom i ekološkom dimenzijom poslovanja), prije svega o informacijama o različitim kategorijama troškova zaštite životne sredine (environmental costs).

Naime, polazeći od naprijed navedenog može se konstatirati da ciljevi zaštite životne sredine i korporativni ciljevi treba da budu integrirani preko tržišnog mehanizma. Na taj način postiže se internalizacija troškova zaštite životne sredine, što dovodi do toga da se poboljšanje ekoloških rezultata pozitivno odražava na rezultat poduzeća (Cullen, 2006, 4-5). Kao informacijska podrška poduzeću u procesu pružanja informacija o utjecaju poduzeća na životnu sredinu i obrnuto, 
služi ekološko upravljačko računovodstvo (Environmental Management Accounting -EMA). EMA osigurava pragmatičan odgovor na kritike da konvencionalno upravljačko računovodstvo nije uspelo da osigura eksplicitno razmatranje pitanja zaštite životne sredine unutar poduzeća, troškova zaštite životne sredine koji su često ,skriveni“ u općim troškovima, kao i da često ignorira potencijalne ekološke koristi (Jasch, 2003; Papaspyropoulos et al., 2012; Xiaomei, 2004).

Naprijed navedeno sugerira da upravljačko računovodstvo, pored interne dimenzije, širi svoj fokusa djelovanja i na eksternu dimenziju, odnosno na strateški aspekt poslovanja poduzeća. Dakle, u suvremenim uvjetima poslovanja koje karakteriziraju stalne promjene i gdje je jedino promjena konstanta, teorija i praksa poseban akcent stavlja na strateško upravljačko računovodstvo i nove koncepte obračuna troškova. Međutim, krajem XX. i početkom XXI. stoljeća, pored strategijskog, sve više se potencira i značaj EMA koje se temelji na konceptu održivog razvoja, čistije proizvodnje i eko-efikasnosti. Imajući u vidu promjene koje karakteriziraju teorijski razvoj upravljačkog računovodstva, postavlja se pitanje: Kakve su tendencije u praksi i da li i u kojoj mjeri je teorija implementirana $u$ poslovanje poduzeća?

\section{NESUKLAĐENOST IZMEĐU TEORIJE I PRAKSE UPRAVLJAČKOG RAČUNOVODSTVA}

Na temelju prethodno učinjenih razmatranja može se steći utisak da se upravljačko računovodstvo razvija u skladu sa promjenljivim uvjetima okruženja. Relevantna naučna i stručna literatura većinom podržavaju ovaj stav, mada zaključujemo kako je većina znanstvenih radova na teorijskom, konceptualnom nivou kada su u pitanju suvremene tehnike, alati i pravci razvoja upravljačkog računovodstva. Također, brojna empirijska istraživanja i studije, prikazane u nastavku, ukazuju na problem neusklađenosti između teorije i prakse upravljačkog računovodstva. U posljednje dvije decenije pojavljuju se istraživanja koja analiziraju faktore koji utječu na implementaciju tehnika strateškog upravljačkog računovodstva (Cravens \& Guilding, 2001; Guilding et al. 2000; Cadez, 2006; Imeokparia, 2008). Ukupni rezultati ovih istraživanja ukazuju na određene probleme, kao što su:

1. računovodstvene tehnike strateškog upravljanja nisu bazirane na strategiji,

2. neke tehnike strateškog upravljačkog računovodstva imaju utjecaj na poboljšanje financijskih performansi,

3. različit intenzitet korištenja tehnika strateškog upravljačkog računovodstva je visok u pojedinim zemljama (detaljnije pogledati: Fowiza, 2011).

Što se tiče tehnika upravljačkog računovodstva, najveći broj empirijskih istraživanja se odnosio na primjenu suvremenih metoda obračuna troškova kao što su 
obračun troškova na bazi aktivnosti (Activity Based Costing - ABC) i obračun zasnovan na ciljnim troškovima (Target Costing - TC). Tako, Gosselin (2007, 641-671) daje sveobuhvatan pregled 1477 radova objavljenih o ABC. On ukazuje na dokaze istraživanja koje je nazvao „ABC paradoks“. Naime, iako se o ABC piše kao o privlačnoj tehnici, prihvaćenoj, poznatoj i proučavanoj na mnogim fakultetima, empirijska istraživanja ukazuju na nizak nivo usvajanja na globalnom nivou. Zaključci istraživanja ukazuju da većina kompanija nikada nije uzimala u obzir ABC i da neke firme koje su ga prihvatile u 1990-im godinama su ga napustile. Istraživanja ukazuju na malu stopu rasta od 2\% u švedskim kompanijama i relativno visoku od 36\% u američkim (Institute of Management Acountants, 1993). Gosselin (2007, 649), također, iznosi da se ABC modeli razlikuju između poduzeća što doprinosi nepreciznosti rezultata ankete.

Istraživanje, provedeno 2006. godine, koje je također obuhvatilo primjenu ABC u praksi ukazuje na podjednaku zastupljenost primjene zajedničke stope za alokaciju općih troškova u Njemačkoj i SAD praksi (oko 21\% u svakoj) i ABC (oko 20\% u svakoj). Također, rezultati istraživanja ukazuju da je opće zadovoljstvo primijenjenim sustavom obračuna troškova u kompanijama u SAD prilično slabo (24\%), dok su u njemačkim kompanijama vrlo zadovoljni primijenjenim sustavima obračuna troškova (77\%) (Krumwiede \& Suessmair, 2007). Interesantno je istaći i istraživanje (Bhimani et al., 2007) provedeno 2006. godine o primjeni ABC u sedam zemalja (Tablica 1).

Tablica 1. Rezultati istraživanja primjene $\mathrm{ABC}$ u odabranim zemljama

\begin{tabular}{|c|c|c|c|c|c|c|c|c|}
\hline $\begin{array}{c}\text { Primjena } \\
\text { ABC }\end{array}$ & Kanada & $\begin{array}{l}\text { Fran- } \\
\text { cuska }\end{array}$ & $\begin{array}{c}\text { Nje- } \\
\text { mačka }\end{array}$ & Italija & \begin{tabular}{|c|} 
Ujedi- \\
njeno \\
Kraljev- \\
stvo
\end{tabular} & SAD & Japan & $\begin{array}{l}\text { Uku- } \\
\text { pno }\end{array}$ \\
\hline $\begin{array}{l}\text { Odbačena } \\
\text { primjena }\end{array}$ & $\begin{array}{c}1 \\
(4,3 \%) \\
\end{array}$ & $\begin{array}{c}1 \\
(2,7 \%)\end{array}$ & $\begin{array}{c}0 \\
(0 \%) \\
\end{array}$ & $\begin{array}{c}3 \\
(15,8 \%) \\
\end{array}$ & $\begin{array}{c}2 \\
(3,8)\end{array}$ & $\begin{array}{c}2 \\
(4,4 \%) \\
\end{array}$ & $\begin{array}{c}57 \\
(69,5 \%) \\
\end{array}$ & $\begin{array}{c}66 \\
(22,7 \%) \\
\end{array}$ \\
\hline $\begin{array}{l}\text { Pilot primje- } \\
\text { na }\end{array}$ & $\begin{array}{c}8 \\
(34,8 \%) \\
\end{array}$ & $\begin{array}{c}4 \\
(10,8 \%) \\
\end{array}$ & $\begin{array}{c}10 \\
(31,2 \%) \\
\end{array}$ & $\begin{array}{c}7 \\
(36,8 \%) \\
\end{array}$ & $\begin{array}{c}8 \\
(15,4 \%) \\
\end{array}$ & $\begin{array}{c}10 \\
(21,8 \%) \\
\end{array}$ & $\begin{array}{c}9 \\
(11,0 \%)\end{array}$ & $\begin{array}{c}56 \\
(19,3 \%)\end{array}$ \\
\hline $\begin{array}{l}\text { Potpuna pri- } \\
\text { mjena }\end{array}$ & $\begin{array}{c}9 \\
(39,1 \%) \\
\end{array}$ & $\begin{array}{c}8 \\
(21,6 \%)\end{array}$ & $\begin{array}{c}16 \\
(50 \%)\end{array}$ & $\begin{array}{c}5 \\
(26,3 \%)\end{array}$ & $\begin{array}{c}29 \\
(55,8 \%)\end{array}$ & $\begin{array}{c}25 \\
(54,4 \%)\end{array}$ & $\begin{array}{c}5 \\
(6,1 \%)\end{array}$ & $\begin{array}{c}97 \\
(33,3 \%)\end{array}$ \\
\hline $\begin{array}{l}\text { Primjena u } \\
\text { većini orga- } \\
\text { nizacijskih } \\
\text { dijelova }\end{array}$ & $\begin{array}{c}5 \\
(21,7 \%)\end{array}$ & $\begin{array}{c}24 \\
(64,9 \%)\end{array}$ & $\begin{array}{c}6 \\
(18,8 \%)\end{array}$ & $\begin{array}{c}4 \\
(21,1 \%)\end{array}$ & $\begin{array}{c}13 \\
(25 \%)\end{array}$ & $\begin{array}{c}9 \\
(19,6)\end{array}$ & $\begin{array}{c}11 \\
(13,4 \%)\end{array}$ & $\begin{array}{c}72 \\
(24,7 \%)\end{array}$ \\
\hline $\begin{array}{l}\text { Broj ispi- } \\
\text { tanika koji } \\
\text { primjenjuju } \\
\text { ili su primje- } \\
\text { njivali ABC }\end{array}$ & 23 & 37 & 32 & 19 & 52 & 46 & 82 & 291 \\
\hline $\begin{array}{l}\text { Ukupan broj } \\
\text { ispitanika }\end{array}$ & 35 & 39 & 73 & 32 & 85 & 57 & 95 & 416 \\
\hline
\end{tabular}

Izvor: Bhimani A., Gosselin M., Ncube M., Okano H., (2007). Activity-Based Costing: How Far Have We Come Internationally?, Cost Management, 21(3), 12-17. 
Primjena ABC, prema podacima danim u tablici 1, iskazana je kao apsolutna veličina i kao relativna veličina $u$ odnosu na broj ispitanika kojima je ABC poznat (primjenjuju ga ili su ga primjenjivali), što znači da je stvarni postotak primjene manji. Iako navedeno istraživanje ima nedostataka koje se odnose na broj ispitanika, strukturu promatranih entiteta u izdvojenim zemljama, odnosno koliko je promatranih entiteta proizvodnog, uslužnog ili trgovinskog tipa i kakva je vjerodostojnost primljenih odgovora od strane ispitanika, ono ukazuje da je primjena ABC još uvijek na niskom nivou u većini zemalja.

Ansari i dr. (2007) predstavili su sveobuhvatan pregled više od 80 publikacija na engleskom i 100 na japanskom jeziku koje se bave ciljnim troškovima. U pitanju su bili uglavnom normativni i tehnički radovi, ali također analizirali su i studije slučaja o primjeni TC u industriji u SAD i Europi. U svom istraživanju su došli do zaključka da je TC u Europi i Americi mlad i primjenjuje se uglavnom u automobilskoj i montažnoj industriji, za razliku od Japana gdje je on dostigao fazu zrelosti.

Polazeći od cilja istraživanja u ovom radu čini se interesantnim i navesti istraživanja Ghosh i Chan (1997), Chan (2002) i Mahfar i Omar (2004). Naime, Ghosh i Chan (1997, 16-18) ukazali su da je napravljen opći napredak u praksi upravljačkog računovodstva u Singapuru, gdje više poduzeća koristi različite računovodstvene tehnike u upravljanju poslovanjem. Međutim, nove tehnike kao što su menadžment kvalitetom i obračun troškova na bazi aktivnosti, polako postaju prihvaćene i korištene od strane lokalnih singapurskih poduzeća, ali ove lokalne kompanije nastavljaju da zaostaju za multinacionalnim kompanijama. Chan (2002), je nakon pet godina proveo sličnu studiju u Singapuru, čiji je cilj bio da istraži praksu upravljačkog računovodstva u toj zemlji. Rezultati su pokazali malo poboljšanje u praksi upravljačkog računovodstva od 1997. Pored toga, utvrđeno je da su singapurska poduzeća neefikasna u korištenju troškovnih alata i da lokalne kompanije izbjegavaju korištenje naprednih tehnika upravljačkog računovodstva. To je zato što napredne tehnike zahtijevaju visok nivo kompleksnosti i visok iznos sredstava za njihovu implementaciju. Mahfar i Omar (2004) u svom istraživanju provedenom u Maleziji ukazuju da u praksi izabranih malezijskih kompanija dominantno mjesto zauzimaju prva i druga faza upravljačkog računovodstva (tradicionalno upravljačko računovodstvo). Korištenje naprednih tehnika upravljačkog računovodstva je još uvijek neznatno u Maleziji i očekuje se da će se u budućnosti situacija promijeniti.

Imajući u vidu da je u prethodnom djelu istaknut $\mathrm{i}$ fokus upravljačkog računovodstva prema održivom razvoju, odnosno prema ekološkoj dimenziji postavlja se pitanje u kojoj mjeri je implementirano ekološko upravljačko računovodstvo u poduzećima. Empirijski dokazi govore da je nivo upotrebe u praksi raznolik. Postoje brojne studije slučaja koje skreću pažnju na koristi od upotrebe EMA (Burritt et al., 2009; Christ \& Burritt, 2013). Također, brojne studije generalno 
podržavaju stav da kada poduzeća ne prepoznaju i ne objašnjavaju ekološke utjecaje povezane sa njihovim aktivnostima, ona riskiraju mogućnosti za poboljšanje ekonomskih i ekoloških performansi (Konar \& Cohen, 2001; Scavone, 2006). Usprkos ovim ohrabrujućim rezultatima, nisu sve studije u suglasnosti i dokazi su parcijalni. Mnogi istraživači ukazuju da je nizak nivo usvajanja EMA, često propraćen preovladavajućim mišljenjem da koristi od njegove implementacije ne opravdavaju troškove (Bartolomeo et al., 2000; Ferreira et al., 2010). Čak i u istraživanjima gdje poduzeća tvrde da sprovode EMA, detaljnijim ispitivanjem utvrđeno je da se radi o izoliranoj implementaciji alata za razliku od "sistematskog i cjelovitog provođenja" (Bartolomeo et al., 2000, 48-50).

Na temelju naprijed navedenog proizlazi da teorijski razvoj upravljačkog računovodstva ne prati i razvoj i primjenu novih upravljačko računovodstvenih koncepata, tehnika i alata u praksi poduzeća. Naime, rezultati empirijskih istraživanja ukazuju na neusklađenost između teorije i prakse upravljačkog računovodstva, odnosno nerazvijena suradnja i nizak nivo povezanosti između istraživača i privrede predstavlja značajan ograničavajući faktor transfera znanja, od akademskih ka profesionalnim računovođama.

\section{ZAKLJUČAK}

Kako bi kompanija preživjela i bila konkurentna na tržištu koje se stalno mijenja, mora uspostaviti zdravu praksu upravljačkog računovodstva. Međutim, u posljednjih nekoliko godina, povećanje raznolikosti proizvoda, skraćenje životnog ciklusa proizvoda, široko rasprostranjena informacijska tehnologija u proizvodnji i pojava svjetskih tržišta proizvoda kao rezultat erozije barijera u trgovini, postavili su intenzivnije izazove za menadžere. Uzimajući ovo u obzir, mnogi istraživači su upozorili da, ako upravljačko računovodstvo želi da održi svoj značaj, mora se prilagoditi kako bi odgovorilo promjenljivim potrebama rukovodilaca. Dakle, razvoj upravljačkog računovodstva treba da bude usmjeren ka novim konceptima, tehnikama i alatima upravljačkog računovodstva koje će da prate promjene koje se događaju u upravljanju proizvodnjom.

Posljednje decenije XX. stoljeća počele su sa velikim obećanjima i dugi niz godina bilo je mnogo entuzijazma od strane profesionalnih i akademskih računovodstvenih zajednica kada je u pitanju strateško i ekološko upravljačko računovodstvo, kao i suvremeni koncepti, tehnike i alati usmjereni na obračun i upravljanje troškova. Međutim, analizom empirijskih istraživanja uočeno je da ne postoji uvjerljiv dokaz da se upravljačko računovodstvo, u obliku u kom je predvidjela teorija, široko upotrebljava u praksi poduzeća. Radovi zasnovani na konceptualnim osnovama u kojima se ističu prednosti strategije, ekološke dimenzije i konceptualni razvoj upravljačkog računovodstva nisu doveli do široke 
rasprostranjenosti i usvajanja istih, čime se otežava utvrđivanje njihovog uspjeha ili implementacije u praksi poduzeća.

Na bazi navedenog, može se zaključiti da iako je menadžerska i računovodstvena, teorijsko-metodološka i stručna literatura bila ažurna i u dovoljnoj mjeri okupirana ovim veoma važnim područjem menadžmenta i računovodstvenog sistema, empirijska istraživanja ukazuju na nedovoljnu zastupljenost suvremenih koncepata, tehnika i alata upravljačkog računovodstva u praksi poduzeća. Otuda su u ovom segmentu računovodstvenog sistema nužne odgovarajuće promjene. Moguće preporuke za poboljšanje prakse upravljačkog računovodstva bi mogle biti sljedeće:

1. ojačati saradnju i aktivan odnos između akademskih i profesionalnih računovođa, posebno u dijelu međusobnog transfera znanja i vještina,

2. ojačati ulogu profesionalnih organizacija u procesima kontinuirane edukacije profesionalnih računovođa,

3. poticati unapređenje i usklađivanje nastavnih planova i programa na svim nivoima obrazovanja sa novinama u upravljačkom računovodstvu,

4. povećati boj edukativnih seminara za računovođe i menadžere poduzeća kako bi se shvatio značaj i uloga računovodstva troškova, posebno zasnovanog na primjeni suvremenih sistema obračuna troškova i sl.

Učinjenim razmatranjima je potvrđena kompleksnost i značajnost razvoja upravljačkog računovodstva, a naročito nužnost adekvatne informacijske podrške i neophodnost poznavanja adekvatne primjene suvremenih koncepata, tehnika i alata upravljačkog računovodstva za formuliranje i implementaciju strategije poduzeća, sagledavanja ekološke dimenzije poslovanja i obračuna i upravljanja troškovima poduzeća. Preostaje pitanje približavanja teorijskih dostignuća primjeni u praksi. Uz navedene preporuke, koje bi poboljšale računovodstvenu praksu, ističe se neophodnost pozitivnog promoviranja upravljačkog računovodstva i njegovih prednosti. To je zadatak, kako obrazovnog sustava, tako i samih istraživača i upravljačkih računovođa u praksi koji treba da budu integrirani u upravljački proces, a posebno u strateški menadžment poduzeća.

Na kraju, glavno ograničenje ovog istraživanja odnosi se na činjenicu da teorijska izlaganja nisu upotpunjena empirijskim istraživanjem autora o praksi upravljačkog računovodstva u bivšim jugoslovenskim republikama. Polazeći od navedenog, ovaj rad bi mogao da posluži kao polazna osnova za empirijska istraživanja navedene problematike u bivšim jugoslovenskim republikama. Također, u budućim istraživanjima treba istražiti primjenu upravljačko računovodstvenih alata u poduzećima i pokušati da se primjenom statističkih tehnika identificira utjecaj veličine poduzeća, pripadnosti industrije, organizacijske kulture na stupanj primjene suvremenih upravljačko računovodstvenih tehnika. 


\section{LITERATURA}

1. Ansari, S. L., Bell, J. F., Okano, H., (2007), A review of literature of target costing and cost management, in Chapman, C., S., Hopwood, A., G., Shields, M., D. (Eds), Handbook of Management Accounting Research, Vol. 2, Elsevier, Oxford, pp. 507-530.

2. Bartolomeo, M., Bennett, M., Bouma, J. J., Heydkamp, P., Wolters, T., (2000), Environmental management accounting in Europe: current practice and future potential, European Accounting Review, Vol. 9., No. 1., pp. 31-52.

3. Bhimani A., Gosselin M., Ncube M., Okano H., (2007), Activity-Based Costing: How Far Have We Come Internationally?, Cost Management, Vol. 21., No. 3., pp. 12-17.

4. Bromwich, M., (1990), The case for strategic management accounting: The role of accounting information for strategy in competitive markets, Acounting, Organizations and Society, Vol. 15., No. 1-2., pp. $27-46$.

5. Bromwich, M., Bhimani, A., (1996), Management Accounting, Pathweys to Progress, CIMA Publishing, London.

6. Brouthers, K. D., Roozen, F. A., (1999), Is It Time to Start Thinking About Strategic Accounting? Long Range Planning, Vol. 32., No. 3., pp. 311- 322.

7. Burritt, R. L., Saka, C., (2006), Environmental management accounting applications and eco-efficiency: case studies from Japan, Journal of Cleaner Production, No. 14., pp. 1262-1275.

8. Burritt, R. L., (2004), Environmental Management Accounting: Roadblocks on the way to the green and pleasant land, Business Strategy and the Environment, No. 13., pp. 13-32.

9. Burritt, R. L., Herzig, C., Tadeo, B. D., (2009), Environmental management accounting for cleaner production: The case of a Philippine rice mill, Journal of Cleaner Production, No. 17., pp. 431-439.

10. Cadez, S., (2006), Strategy, Market orientation, and Company performance: the mediating role of Strategic Management Accounting Systems, paper presented at the Conference "Integrating Global Organization: the role of Performance Measurement Systems", July 13-14, Siena, Italy

11. Cadez, S., Guilding, C., (2008), An exploratory investigation of an integrated contingency model of strategic management accounting, Accounting, Organizations and Society, Vol. 33., No. 4., pp. 836-863.

12. Chan, Y. K., (2002), Management Accounting Practices in Singapure, a paper presentet at the "Asian Management Acounting Forum", November 1-4, Fukuoka, Japan 
13. Christ, K. L., Burritt, R. L., (2013), Environmental management accounting: the significance of contigent variables for adoption, Journal of Cleaner Production, No. 41., pp. 163-173.

14. Cooper, R., Kaplan, R., (1988), How Cost Accounting Distors Product Costs, Management Accounting, April, pp. 20-27.

15. Cravens, K. S., Guilding, C., (2001), An empirical study of the application of strategic management accounting techniques, Advances in Management Accounting, No. 10., pp. 95-124.

16. Cullen, D., (2006), Environmental Management Accounting: The State Of Play, Journal of Business \& Economics Research - October, Vol. 4., No. 10., pp. 1-6.

17. Ferreira, A., Moulang, C., Hendro, B., (2010), Environmental management accounting and innovation: an exploratory analysis, Accounting, Auditing and Accountability Journal, Vol. 23., No. 7., pp. 920-948.

18. Fowiza, R., (2011), Strategic Management Accounting Techniques: Relationship with Business Strategy and Strategic Effectiveness of Manufacturing Organizations in Bangladesh, World Journal of Management, Vol. 3., No. 2., pp. 54-69.

19. Ghosh, B. C., Chan, Y. K., (1997), Management Accounting in Singapure Well in Place? Managerial Auditing Journal, Vol. 12., No. 1., pp. 16-18.

20. Gosselin, M., (2007), A review of activity-based costing: technique, implementation, and consequences, in Chapman, C.S., Hopwood, A.G. and Shields, M.D. (Eds), Handbook of Management Accounting Research, Vol. 2., Elsevier, Oxford, pp. 641-671.

21. Guilding, C., Cravens, K. S., Tayles, M., (2000), An international comparison of strategic management accounting practices, Management Accounting Research, Vol. 11., pp. 113-135.

22. Imeokparia, A. L., (2008), Management Accounting Techniques and Manufacturing Companies in Nigeria, Journal of Research in National Development, Vol. 6, No. 2.

23. International Federation of Accountants Committee (IFAC)., (1998), Management accounting concepts, March

24. Janjić, V., Jovanović, D., (2016), Informaciona podrška strategijskog upravljačkog računovodstva konkurentnosti preduzeća, U: Marinković, V., Janjić, V., Mićić, V. (red.). "Unapređenje konkurentnosti privrede Republike Srbije", Ekonomski fakultet Univerziteta u Kragujevcu,Kragujevac, Srbija, str. 373-382.

25. Jasch, C., (2003), The use of Environmental Management Accounting (EMA) for identifying environmental costs, Journal of Cleaner Production, No. 11., pp. 667-676. 
26. Johnson, T. H., Kaplan, R. S., (1987), Relevance lost: the rise and fall of management accounting, Harvard Business School Press, Boston.

27. Jovanović, D., Janjić, V., Janković, M., (2014), Uticaj veličine preduzeća na implementaciju savremenih sistema obračuna troškova: slučaj Srbije, Teme, Vol. 38., No. 3., str. 1095-1114.

28. Kamal, S., (2015), Historical Evolution on Management Acounting, The Cost and Management, Vol. 43., No. 4., pp. 12-19.

29. Kaplan, R., (1982), Advanced Management Accounting, Prentice Hall, Inc., Englewood Cliffs, NJ.

30. Konar, S., Cohen, M. A., (2001), Does the market value environmental performance? Review of Economics and Statistics, Vol. 83., No. 2., pp. 2814-2890.

31. Krumwiede, K., Suessmair A., (2007), Getting Down to Specifics on RCA, Strategic Finance, jun, pp. 51-55.

32. Mahfar, R., Omar, N., (2004), The Current State of Management Accounting Practice in Selected Malaysian Companies: An Empirical Evidence, a paper presented at the International Business Management Conference 2004, Universiti Tenaga Nasional.

33. Malinić, D., Milićević, V., Stevanović, N., (2012a), Upravljačko računovodstvo, Centar za izdavačku delatnost Ekonomskog fakulteta u Beogradu, Beograd

34. Malinić, S., Jovanović, D., Janković, M., (2012b), Competitive Management Accounting - Response to the Challenges of Strategic Business Decision Making, Facta Universitatis. Series: I, Economics and Organization, Vol. 9., No. 3., pp. 297-309.

35. Milićević, V., (2003), Strategijsko upravljačko računovodstvo, Centar za izdavačku delatnost Ekonomskog fakulteta u Beogradu, Beograd

36. Nishimura, A., (2002), Asia Economic Grouth and Mangement Accounting, Malaysian Accounting Review, Vol. 1., No. 1., pp. 87-101.

37. Papaspyropoulos, K. G., Blioumis, V., Christodoulou, A. S., Birtsas, P. K., Skordas, K. E., (2012), Challenges in implementing environmental management accounting tools: the case of a nonprofit forestry organization, Journal of Cleaner Production, No. 29-30., pp. 132-143.

38. Scavone, G. M., (2006), Challenges in internal environmental management reporting in Argentina, Journal of Cleaner Production, No. 14., pp. 1276-1285.

39. UNDESA/DSD, (2002), United Nations Division for Sustainable Development. Environmental Management Accounting: Policies and Linkages, New York/Geneva: United Nations Publications, http://www.un.org/esa/sustdev/ sdissues/technology/estema1.htm 
40. Waweru, N. M., (2010), The origin and evolution of management accounting: a review of the theoretical framework, Problems and Perspectives in Management, Vol. 8., No. 3., pp. 165-182.

41. Xiaomei, L., (2004), Theory and practice of environmental management accounting: experience of implementation in China, International Journal of Technology Management and Sustainable Development, Vol. 3., No. 1., pp. 47-57. 


\title{
Dejan Jovanović, PhD
}

Faculty of Economics, University of Kragujevac, Kragujevac, Serbia djovanovic@kg.ac.rs

\section{Ivana Medved, $\mathrm{PhD}$}

Faculty of Economics, University of Novi Sad, Subotica, Serbia

ivana@ef.uns.ac.rs

\section{DEVELOPMENT AND NECESSITY OF CHANGES IN THE FOCUS OF MANAGEMENT ACCOUNTING}

Received: August 28, 2018

Accepted: September 24, 2018

Review

\begin{abstract}
Over the past two decades, the environment in which a management accounting has been playing its role begins to change rapidly. In line with changes that have taken place in the environment, businesses and management, accountants had to redesign the existing accounting information system. Considering that management accounting is the most dynamic part of this system, according to expectations, it has had most of the changes. The aim of the research in this paper is to demonstrate the evolution of management accounting, its current position and future directions of development. Starting from the above, the methodological procedures and techniques related to social sciences will be applied, that is qualitative methodology based on the study and descriptive analysis of the defined goal of the research. The most important conclusion is that management accounting changes more its focus towards the strategic dimension of business and the concept of sustainable development, as well as that there is imbalance between the theory and practice of management accounting.
\end{abstract}

Keywords: management accounting, strategic management accounting, environmental management accounting, activity-based costing

JEL: M41 